\title{
Development of microsatellite markers in the razor clam Solen marginatus (Bivalvia: Solenidae)
}

\author{
Marta Francisco-Candeira ${ }^{\text {a }}$, Ana González-Tizón ${ }^{\text {ab }}$, Miguel A. Varela ${ }^{\text {ab }}$ and Andrés Martínez- \\ Lage $^{\mathrm{ab} \dagger}$ \\ a Departamento de Biología Celular y Molecular, Universidade da Coruña, A Zapateira s/n, 15071 La Coruña, \\ Spain. \\ ${ }^{\mathrm{b}}$ Instituto Universitario de Estudos Marítimos, Universidade da Coruña, Campus de Elviña, Ed. Servizos Centrais \\ de Investigación, 15071 La Coruña, Spain.
}

Journal of the Marine Biological Association of the United Kingdom, volume 87, issue 4, pages 977-978, August 2007

Submitted 31 January 2007. accepted 10 May 2007, first published 30 July 2007

\section{How to cite:}

Francisco-Candeira, M., González-Tizón, A., Varela, M., \& Martínez-Lage, A. (2007) Development of microsatellite markers in the razor clam Solen marginatus (Bivalvia: Solenidae). J. Mar. Biol. Ass. U.K., 87(4), 977-978. DOI:10.1017/S0025315407057207

\begin{abstract}
Four microsatellite loci in the razor clam Solen marginatus are described. Loci were isolated from the sequences of intersimple sequence repeat (ISSR) markers and an enriched library. Detailed analysis of these sequences led to the design of eight primer pairs. Allelic variation was assessed in 20 individuals from Redondela, Spain. The genetic variation observed in the markers presented here will be useful for future studies on the population structure of Solen marginatus in the wild and for aquaculture of this species.
\end{abstract}

The razor clam Solen marginatus is a bivalve mollusc belonging to the family Solenidae, common on the European Atlantic coast, the north-west coast of Africa and the Mediterranean. Razor clams are harvested fisheries in several countries. Given its importance, there is an increasing interest in the development of genetic markers to manage natural stocks properly, implement future stock selection programmes and maintain ecological richness.

Microsatellites are useful genetic markers because they are usually highly polymorphic, codominant and multi-allelic. Recently, polymorphic microsatellite loci were characterised in the related razor clam Ensis siliqua (Varela et al., 2007). However, to date there are no microsatellite markers available to study other razor clams such as the solenids. Hence, the purpose of this study was to isolate and characterise microsatellites in S. marginatus.

Solen marginatus samples were collected from Redondela (north-western Spain). Genomic DNA was extracted for each individual using a Chelex protocol (Walsh et al., 1991). A set of microsatellite markers were developed in Solen marginatus using two different approaches: (i) construction of two enriched libraries for tri- and dinucleotide repeat motives; and (ii) from Inter Simple Sequence Repeat (ISSR) markers. For the construction of the enriched libraries, genomic DNA was digested with RsaI restriction enzyme. DNA fragments ranging from 200-1000 bp were isolated and ligated to adaptors RSA21 and RSA25 (Edwards et al., 1996). Ligated fragments were amplified using adaptor RSA21 
as primer. The hybridisation of fragments was performed using biotinylated repeat sequences $(\mathrm{GT})_{8}$ and $(\mathrm{CTT})_{6}$. Subsequently, fragments were recovered with streptavidin-coated magnetic spheres (Promega). The eluted fragments were re-amplified using the RSA21 adaptor primer. Enriched fragments were ligated into plasmid PCR2.1TOPO TA vector and transformed into Escherichia coli TOPO10F' competent cells (Invitrogen). Plasmid DNA from positive colonies was isolated, purified (QIAprep Spin Miniprep, QIAgene) and sequenced using a capillary array electrophoresis sequencer CEQ 8000 Genetic Analysis System (Beckman Coulter).

The ISSR technology is based on the amplification of regions between inversely-oriented closely-spaced microsatellite sequences by a single primer or a pair of primers based on SSRs anchored at 5'. We amplified ISSR markers from one individual using the following anchored primers: HVG(GT) ${ }_{7}$, KKVRVRV(CT) $)_{6}, \mathrm{KRV}(\mathrm{CT})_{9}, \mathrm{YG}(\mathrm{CT})_{9}, \mathrm{YG}(\mathrm{GA})_{9}$ and $\mathrm{YG}(\mathrm{CA})_{9}$. Amplifications were carried out in a PTC-100 (MJ Research) thermocycler programmed with a touchdown cycle, with an initial step at $94^{\circ} \mathrm{C}$ ( $2 \mathrm{~min})$, followed by $94^{\circ} \mathrm{C}(20 \mathrm{~s}), 68^{\circ} \mathrm{C}(30 \mathrm{~s})$ and $72^{\circ} \mathrm{C}(2 \mathrm{~min})$. The annealing temperature decreased $1^{\circ} \mathrm{C}$ for each of the subsequent 12 cycles, followed by 22 cycles at $94^{\circ} \mathrm{C}(20 \mathrm{~s}), 55^{\circ} \mathrm{C}(30 \mathrm{~s})$ and $72^{\circ} \mathrm{C}(2$ min), with a final extension at $72^{\circ} \mathrm{C}(5 \mathrm{~min})$. Amplification of ISSR markers was conducted in $25 \mu \mathrm{l}$ volumes consisting of $1 \times \mathrm{NH}_{4}$ reaction buffer $\left(16 \mathrm{mM}\left(\mathrm{NH}_{4}\right)_{2} \mathrm{SO}_{4} ; 67 \mathrm{mM}\right.$ Tris-HCl, $\mathrm{pH} 8.8 ; 0.1 \%$ Tween-20), $1 \mu \mathrm{M}$ primer, $0.2 \mathrm{mM}$ of each dNTP, $5.2 \mathrm{mM} \mathrm{MgCl}$, $0.75 \mathrm{U}$ Taq DNA polymerase (Bioline), and $20 \mathrm{ng}$ of genomic DNA. The ISSR fragments amplified were ligated directly into the plasmid and sequenced. The analysis of these sequences revealed that all of them contained a microsatellite at the $3^{\prime}$ and 5' ends of the insert, and 14 of them had internal microsatellites. These results indicate that the ISSR technology is effective and applicable to the development of microsatellite markers for Solen marginatus.

Four primer pairs were designed from the enriched library and four other pairs from the ISSR fragments using the software OLIGO (Table 1). Allelic variation was assessed in 20 individuals of Solen marginatus and PCR conditions for each locus were determined with a gradient thermocycler over a range of temperatures between 45 and $65^{\circ} \mathrm{C}$. The PCR amplifications were conducted in $25 \mu \mathrm{L}$ reactions that included a mixture containing $20 \mathrm{ng}$ genomic DNA, $1 \times$ Roche Taq PCR buffer $(10 \mathrm{mM}$ Tris-HCl, $\mathrm{pH} 8.3 ; 50 \mathrm{mM} \mathrm{KCl}), 0.2 \mu \mathrm{M}$ each of forward and reverse primers, $0.2 \mathrm{mM}$ of each dNTP, 2-2.4 mM $\mathrm{MgCl}_{2}$, and $0.75 \mathrm{U} \mathrm{Taq}$ DNA polymerase (Roche). Conditions for PCR included: $94^{\circ} \mathrm{C}$ ( $2 \mathrm{~min}$ ), followed by 30 cycles at $92^{\circ} \mathrm{C}(1 \mathrm{~min}), 60^{\circ} \mathrm{C}(1 \mathrm{~min})$, and $72^{\circ} \mathrm{C}(30 \mathrm{~s})$ with a final extension step at $72^{\circ} \mathrm{C}(10 \mathrm{~min})$.

We used an Agilent 2100 Electrophoresis Bioanalyzer to analyse microsatellite polymorphism revealing the number of heterozygotes. This instrument is equipped with a fluorescence detection system that leads to high detection sensitivity, and the DNA sample size is estimated by comparison with standards (Panaro et al., 2000). This analysis allowed us to discard microsatellite primer pairs that yielded no amplification or monomorphic fragments for further studies. However, we detected variation of about 5\% in the sizing of fragments between different runs of the same PCR reaction as previously described by Hierro et al. (2004); therefore, the ranges of allele sizes should be considered approximations. Of the eight primers designed to amplify unique sequence microsatellites, four failed to amplify in all individuals (Sm187, Sm192, Sm167, Sm280), one was monomorphic (Sm221), and three produced a clear polymorphic banding pattern (Sm230, Sm213, Sm372). The heterozygosity values observed ranged from 0.1667 to 0.9545 . These microsatellite markers could be valuable for future population and genetic mapping studies. 
Table 1. Characterization of microsatellites in 20 Solen marginatus razor clams.

\begin{tabular}{|c|c|c|c|c|c|c|c|c|}
\hline Locus & EMBL no. & $\begin{array}{l}\text { Repeat } \\
\text { motif }\end{array}$ & Method & Primer sequence (5'-3') & {$\left[\mathrm{MgCl}_{2}\right]$} & $\mathbf{T}_{\mathrm{A}}$ & Sizes (bp) & Ho \\
\hline $\operatorname{Sm} 230$ & AM422786 & $(\mathrm{CTA})_{7}$ & & $\begin{array}{l}\text { F: ATTTGTATGCGTGCCTTTTGA } \\
\text { R: TCGTGGGGGGATAGAGTAACA }\end{array}$ & $1.5 \mathrm{mM}$ & $58^{\circ} \mathrm{C}$ & $215-230$ & 0.167 \\
\hline $\operatorname{Sm} 187$ & AM422785 & $(\mathrm{AC})_{10}$ & & $\begin{array}{l}\text { F: TGAAATATACAGGAGGAAAATACCC } \\
\text { R: GGAAAGGGTTAGGGTTAGGGT }\end{array}$ & $2.5 \mathrm{mM}$ & $53^{\circ} \mathrm{C}$ & - & - \\
\hline $\operatorname{Sm} 213$ & AM422785 & $(\mathrm{AC})_{7}$ & ISSR & $\begin{array}{l}\text { F: ACCCAAATACACAAACCGAGG } \\
\text { R: GCTCGGAAAAAATAACTCGCT }\end{array}$ & $1.5 \mathrm{mM}$ & $58^{\circ} \mathrm{C}$ & $210-250$ & 0.955 \\
\hline $\operatorname{Sm} 221$ & AM422787 & $(\mathrm{TA})_{5}$ & & $\begin{array}{l}\text { F: TATACCAGGACACACGCATTTCAT } \\
\text { R: AGTGCGTGACCGAAAAACCTT }\end{array}$ & $2.5 \mathrm{mM}$ & $58^{\circ} \mathrm{C}$ & 225 & 0 \\
\hline Sm192 & AM422781 & $(\mathrm{CA})_{7}$ & & $\begin{array}{l}\text { F: CTTAGCTCACGCTTAACACCAGA } \\
\text { R: CCTTGTGTGAACGAAATGTCTCT }\end{array}$ & $1.5 \mathrm{mM}$ & $58^{\circ} \mathrm{C}$ & - & - \\
\hline Sm167 & AM422782 & $(\mathrm{AT})_{6}(\mathrm{GT})_{16}$ & $\begin{array}{l}\text { Enriched } \\
\text { library }\end{array}$ & $\begin{array}{l}\text { F: ATTAATCATTAGCGCTGCG } \\
\text { R: CACTTTGTAGGTTACACAAACA }\end{array}$ & $2.5 \mathrm{mM}$ & $54^{\circ} \mathrm{C}$ & - & - \\
\hline Sm372 & AM422784 & $(\mathrm{CTT})_{15}$ & & $\begin{array}{l}\text { F: GAAAGGTAAAACACAGCTATGG } \\
\text { R: TTGTTTAACACCTCACCTTTGG }\end{array}$ & $1.5 \mathrm{mM}$ & $55^{\circ} \mathrm{C}$ & $335-375$ & 0.438 \\
\hline $\operatorname{Sm} 280$ & AM422783 & $(\mathrm{CTT})_{30}$ & & $\begin{array}{l}\text { F: TTATTAAGTCCCCCAAACGAAG } \\
\text { R: AACATTTACATACAGGACCATCC }\end{array}$ & $1.5 \mathrm{mM}$ & $58^{\circ} \mathrm{C}$ & - & - \\
\hline
\end{tabular}

Ho, observed heterozygosity; $\mathrm{T}_{\mathrm{A}}$, annealing temperature 
This work was funded by a Xunta de Galicia grant (PGIDT03MA10301PR). This research was also supported by a predoctoral fellowship from Xunta de Galicia awarded to M.V

\section{References}

Edwards, K.J., Barker, J.H., Daly, A., Jones, C. \& Karp, A., 1996. Microsatellite libraries enriched for several microsatellite sequences in plants. Biotechniques, 20, 758-760.

Hierro, N., González, A., Mas, A. \& Guillamón, J.M., 2004. New PCR-based methods for yeast identification. Journal of Applied Microbiology, 97, 792-801.

Panaro, N.J., Yuen, P.K., Sakazume, T., Fortina, P., Kricka, L.J. \& Wilding, P., 2000. Evaluation of DNA fragment sizing and quantification by the Agilent 2100 Bioanalyzer. Clinical Chemistry, 46, 1851-1853.

Varela, M.A., González-Tizón, A., Francisco-Candeira, M. \& Martínez-Lage, A., 2007. Isolation and characterization of polymorphic microsatellite loci in the razor clam Ensis siliqua. Molecular Ecology Notes, 7, 221-222.

Walsh, P.S., Petzger, D.A. \& Higuchi, R., 1991. Chelex 100 as a medium for simple extraction of DNA for PCR-based typing from forensic material. Biotechniques, 10, 506-513.

\footnotetext{
* This article has been published in a revised form in [Journal of the Marine Biological Association of the United Kingdom] [https://doi.org/10.1017/S0025315407057207]. This version is free to view and download for private research and study only. Not for re-distribution, re-sale or use in derivative works. () Marine Biological Association of the United Kingdom.

+ andres@udc.es
} 